\title{
PENGARUH MODEL PEMBELAJARAN INQUIRY TRAINING TERHADAP HASIL BELAJAR SISWA PADA MATERI POKOK SUHU DAN KALOR
}

\author{
Nita Ariany Purba dan Makmur Sirait \\ Jurusan Fisika FMIPA Universitas Negeri Medan \\ nita.ariany15@gmail.com
}

\begin{abstract}
ABSTRAK
Penelitian ini bertujuan untuk mengetahui adanya pengaruh penggunaan model pembelajaran inquiry training terhadap hasil belajar siswa dan mengetahui aktivitas siswa. Jenis penelitian ini adalah quasi eksperimen dengan two group pretest-posttest design. Populasi dalam penelitian adalah seluruh siswa kelas $\mathrm{X}$ Semester II yang terdiri dari 5 kelas berjumlah 235 orang. Pengambilan sampel dilakukan dengan cara cluster random sampling sebanyak 2 kelas yaitu kelas X-1 yang berjumlah 39 orang sebagai kelas eksperimen dan kelas X-4 yang berjumlah 35 orang sebagai kelas kontrol. Instrumen yang digunakan yaitu tes hasil belajar berbentuk pilihan berganda dengan jumlah 15 soal dan lembar observasi aktivitas siswa yang diamati oleh dua observer. Teknik analisis data yang digunakan adalah uji t setelah data berdistribusi normal dan homogen. Berdasarkan analisis data dan uji hipotesis diperoleh bahwa ada pengaruh model pembelajaran inquiry training terhadap hasil belajar siswa pada materi pokok suhu dan kalor dan aktivitas siswa dikategorikan aktif.
\end{abstract}

Kata kunci : inquiry training, hasil belajar.

\begin{abstract}
The purpose of this research is to know the effect of inquiry learning model training on student learning outcomes and student's activity. The type of research is experimental research with desain is two group pretest-posttest design. Population in the study were all students of class $X$ semester II consisting of 5 class numbered 235 people. Sampling was done by cluster random sampling two classes of class $X-1$ which amounts to 39 people's as the experimental class and the class $X^{-}$ 4 which amounts to 35 people's as the control class. The instruments used are shaped achievement test with 15 multiple-choice questions and student activity observation sheet was observed by two observers. Data analysis technique used was the $t$ test after the data were normally distributed and homogeneous. Based on data analysis and hypothesis testing showed that there is influence of inquiry learning model training on learning outcomes of students in the subject matter and the temperature of the heat and activity of students categorized as active.
\end{abstract}

Keywords : inquiry training, learning outcomes

\section{PENDAHULUAN}

Pendidikan adalah segala pengalaman belajar yang berlangsung dalam segala lingkungan dan sepanjang hidup (Mudyahardjo, 2008 : 3). Pendidikan merupakan faktor utama dalam pembentukan pribadi manusia.
Oleh sebab itu, hampir semua negara menempatkan variabel pendidikan sebagai sesuatu yang penting dan utama dalam konteks pembangunan bangsa dan negara sehingga perlu diperhatikan mutunya. 
Kenyataan yang ada saat ini bahwa masih rendahnya hasil belajar yang diperoleh oleh siswa, dimana salah satunya pada mata pelajaran fisika. Hal itu disebabkan oleh beberapa faktor. Sirait dan sahyar (2013 : 9) mengatakan selama proses pembelajaran guru jarang mengajak siswa untuk langsung melakukan pengamatan atau praktikum mengenai materi yang diajarkan secara nyata melainkan hanya melakukan demonstrasi saja di depan kelas. Hal tersebut dikarenakan guru beranggapan dengan menggunakan metode demonstrasi tidak menghabiskan waktu yang banyak dan dapat secara cepat menyelesaikan materi yang sedang diajarkan sehingga membuat siswa kurang mampu melakukan praktikum.

Begitu juga halnya Trisno, dkk (2014 : 14) bahwa hasil belajar fisika masih rendah dikarenakan proses pembelajaran yang ditemukan secara umum lebih menekankan pada pencapaian tuntutan kurikulum dan masih ada sebagian guru belum menciptakan suasana belajar yang menarik dan menyenangkan sehingga siswa tidak termotivasi dan merasa terbebani dalam belajar fisika. Sama halnya menurut Hayati dan suyati (2013 : 25) mengatakan dalam pembelajaran guru lebih sering menggunakan model pembelajaran konvensional seperti mengajak siswa untuk membaca bahan ajar, menghafal yang mengakibatkan siswa cenderung merasa bosan, jengkel dan tidak adanya kemauan siswa untuk mendalaminya.

Berdasarkan hasil observasi yang dilakukan peneliti di SMA PAB 8 Saentis Deli Serdang dengan menyebarkan angket kepada siswa dan wawancara kepada guru bidang studi fisika juga menunjukkan hasil yang sama, yaitu diketahui bahwa hasil belajar fisika yang diperoleh siswa masih rendah atau masih di bawah dari nilai ketuntasan minimal. Dari hasil pembagian angket kepada 46 siswa,
$84,78 \%$ atau 39 siswa tidak menyukai pelajaran fisika dengan alasan fisika itu tidak terlepas dari rumus-rumus atau perhitungan yang rumit dan menjenuhkan. Hal ini dikarenakan $82,60 \%$ atau 38 siswa menyatakan bahwa fisika merupakan pelajaran yang sulit dan membosankan. Kemudian ditambah lagi 84,78 \% atau 39 siswa mengatakan bahwa metode mengajar guru di kelas kurang bervariasi sehingga mereka kurang termotivasi untuk mempelajari fisika, karena guru lebih sering menyuruh siswa mencatat dan mengerjakan soalsoal. Dari hasil angket juga diketahui bahwa hasil belajar fisika siswa yang diperoleh masih di bawah KKM yang telah ditentukan oleh pihak sekolah.

Berdasarkan kondisi di atas perlu diterapkan suatu model pembelajaran yang sesuai, mampu meningkatkan hasil belajar fisika siswa, dan dapat membuat siswa menjadi lebih aktif dalam proses pembelajaran (student centered) sedangkan guru hanya sebagai fasilitator (membimbing). Mengingat fisika merupakan salah satu pelajaran IPA yang mempelajari gejala-gejala dan fenomena-fenomena alam yang sering terjadi dalam kehidupan sehari-hari. Fisika berusaha mengungkapkan konsep yang sederhana mengenai gejala dan fenomena yang terjadi dikehidupan sehari-hari. Konsep ini dapat ditemukan siswa melalui eksperimen yang langsung dilakukan siswa itu sendiri. Maka model pembelajaran yang cocok untuk digunakan salah satunya adalah model pembelajaran inquiry training. Menurut Joyce, dkk (2011 : 201) model pembelajaran inquiry training dirancang untuk membawa siswa secara langsung ke dalam proses ilmiah melalui latihan-latihan yang dapat memadatkan proses ilmiah tersebut ke dalam periode waktu yang singkat.

Penelitian-penelitian yang relevan dengan model pembelajaran inquiry training ini sudah dilakukan 
dalam penelitian sebelumnya diantaranya diteliti oleh Tumanggor (2012 : 51) menyatakan bahwa nilai rata-rata hasil belajar di kelas yang menggunakan model pembelajaran inquiry training adalah 74,63 sedangkan dengan menggunakan model pembelajaran konvensional memiliki nilai rata-rata 68,13 . Begitu juga dalam penelitian oleh Sucita (2013 : 56) menyatakan bahwa dengan menggunakan model pembelajaran inquiry training siswa mengalami peningkatan nilai hasil belajar sebesar 75,43 sedangkan menggunakan model pembelajaran konvensional hasil belajar siswa sebesar 64,42.

Penelitian ini bertujuan untuk mengetahui pengaruh model pembelajaran inquiry training terhadap hasil belajar siswa pada materi pokok Suhu dan Kalor.

\section{METODE PENELITIAN}

Penelitian ini dilaksanakan di SMA PAB 8 Saentis Deli Serdang Jalan Kaliserayu PTPN II Saentis Kabupaten Deli Serdang dan waktu pelaksanaannya pada Tahun Pelajaran 2014/2015 Semester II.

Populasi dalam penelitian ini adalah seluruh siswa kelas X SMA PAB 8 Saentis Deli Serdang T.P 2014/2015 berjumlah 5 kelas dengan jumlah siswa 235 orang. Pada penelitian ini sampel terdiri dari dua kelas yang dipilih dengan teknik cluster random sampling yaitu kelas $\mathrm{X}_{1}$ yang berjumlah 39 orang sebagai kelas eksperimen yang menerapkan model pembelajaran inquiry trainingdan kelas $\mathrm{X}_{4}$ yang berjumlah 35 orang sebagai kelas kontrol dengan menerapkan model pembelajaran konvensional.

Instrumen yang digunakan dalam penelitian ini adalah observasi aktivitas siswa selama pembelajaran dan tes hasil hasil belajar sebanyak 20 soal pilihan berganda dengan 5 option sebelum divalidasi. Setelah divalidasi tes hasil belajar menjadi 15 soal yang akan diberikan pada pretes dan postes.
Uji validitas yang digunakan dalam penelitian ini yaitu validitas isi dan validitas ramalan.

Jenis penelitian yang digunakan dalam penelitian ini adalah quasi eksperimen.

Desain penelitian yang digunakan yaitu two group pre test-pos test design seperti yang terlihat pada Tabel 1 .

Tabel 1 .Two group pretest-postest design

\begin{tabular}{|l|c|c|c|}
\hline \multicolumn{1}{|c|}{ Kelas } & $\begin{array}{c}\text { Tes } \\
\text { awal } \\
\left(\mathrm{Y}_{1}\right)\end{array}$ & $\begin{array}{c}\text { Perlaku } \\
\text { an } \\
(\mathrm{X})\end{array}$ & $\begin{array}{c}\text { Tes } \\
\text { Akhir } \\
\left(\mathrm{Y}_{2}\right)\end{array}$ \\
\hline Eksperimen & $\mathrm{Y}_{1}$ & $\mathrm{X}_{1}$ & $\mathrm{Y}_{2}$ \\
\hline Kontrol & $\mathrm{Y}_{1}$ & $\mathrm{X}_{2}$ & $\mathrm{Y}_{2}$ \\
\hline
\end{tabular}

Keterangan :

$\mathrm{X}_{1}$ : Pembelajaran dengan menggunakan model pembelajaran inquiry training pada materi pokok suhu dan kalor.

$\mathrm{X}_{2}$ : Pembelajaran dengan menggunakan model pembelajaran konvensional pada materi pokok suhu dan kalor

$\mathrm{Y}_{1}$ : Pretes diberikan pada kelas eksperimen dan kelas kontrol sebelum perlakuan. Tes yang diberikan berupa tes hasil belajar pada materi pokok suhu dan kalor.

$\mathrm{Y}_{2}$ : Postes diberikan setelah perlakuan pada kelas eksperimen dan kelas kontrol.

Penelitian ini diawali dengan memberikan pretes kepada kedua kelas yang bertujuan untuk mengetahui kemampuan awal siswa. Dalam hal ini kemampuan awal siswa dapat diketahui dengan melakukan uji $\mathrm{t}$ dua pihak dengan syarat data harus berdistribusi normal dan homogen. Selanjutnya kedua kelas diberi perlakuan yang berbeda yaitu pada kelas eksperimen diberi perlakuan dengan menggunakan model pembelajaran inquiry training 
sedangkan kelas kontrol diberi perlakuan menggunakan model pembelajaran konvensional. Setelah diberi perlakuan terhadap kedua kelas maka dilakukan postes yang bertujuan untuk mengetahui apakah ada pengaruh yang signifikan penggunaan model pembelajaran inquiry training terhadap hasil belajar siswa. Hal ini dapat diketahui dengan cara melakukan uji t satu pihak. Dimana syarat uji $t$ satu pihak data postes tersebut harus berdistribusi normal dan homogen.

\section{HASIL DAN PEMBAHASAN}

Berdasarkan data hasil penelitian diperoleh nilai rata-rata pretes siswa pada kelas eksperimen sebelum diberi perlakuan adalah 33,33, sedangkan dikelas kontrol diperoleh nilai rata-rata pretes adalah 32,00 .

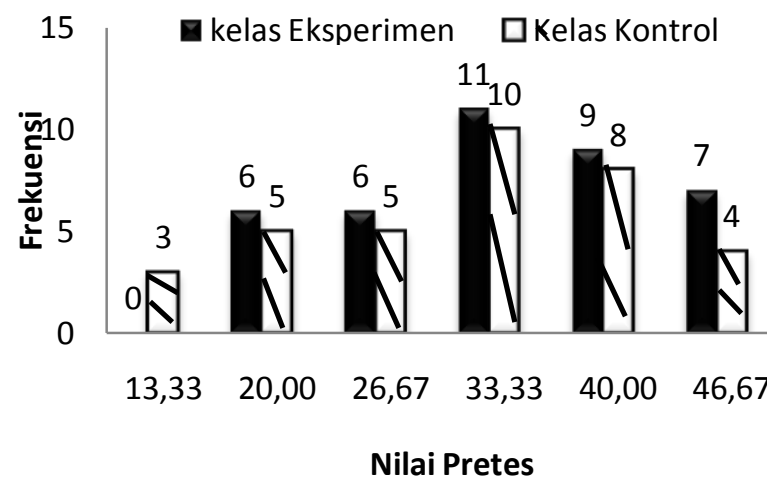

Gambar 1 Diagram Batang Data Pretes Kelas Eksperimen dan Kelas Kontrol

Gambar 1 dapat dilihat bahwa nilai pretes untuk kelas eksperimen dan kelas kontrol tidak jauh berbeda. Hal ini diketahui bahwa kemampuan awal pada kedua kelas sama.

Langkah selanjutnya kedua kelas diberi perlakuan yang berbeda yaitu pada kelas eksperimen diberi perlakuan dengan menggunakan model pembelajaran inquiry training sedangkan pada kelas kontrol diberi perlakuan dengan menggunakan model pembelajaran konvensional. Setelah diberikan perlakuan yang berbeda, kedua kelas tersebut diberikan postes dengan soal yang sama dengan pretes maka diperoleh hasil nilai rata-rata postes kelas eksperimen 71,97 sedangkan kelas kontrol nilai rata-rata postes adalah 63,81 .

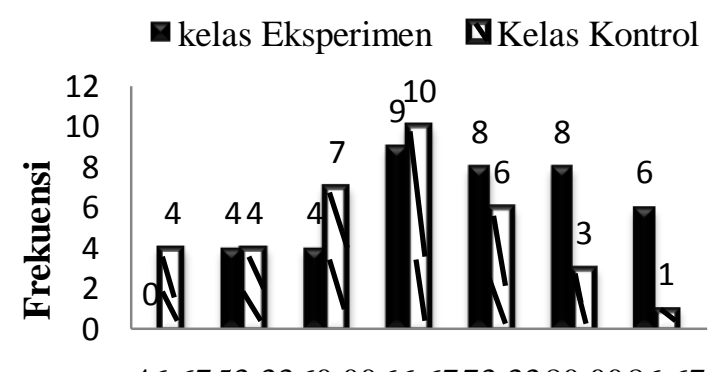

$46,6753,3360,0066,6773,3380,0086,67$

Nilai Postes

Gambar 2 Diagram Batang Data Postes Kelas Eksperimen dan Kelas Kontrol

Gambar 2 diketahui bahwa nilai di kelas eksperimen lebih banyak yang mendapatkan nilai tinggi dibandingkan di kelas kontrol, Begitu juga hal nya kelas eksperimen lebih sedikit yang mendapatkan nilai rendah dibandingkan di kelas kontrol. Hal ini menunjukkan bahwa hasil penelitian diketahui bahwa ada pengaruh penggunaan model pembelajaran inquiry training terhadap hasil belajar siswa pada materi pokok suhu dan kalor di kelas X semester II SMA PAB 8 Saentis Deli Serdang T.P. 2014/2015, ditunjukkan dengan nilai rata-rata postes di kelas eksperimen yaitu 71,97 dan nilai rata-rata postes di kelas kontrol yaitu 63,81 .

Hal ini di dukung oleh Sirait (2012 : 25) yang dikutip dari jurnal dikfis pascasarjana unimed yang menyatakan bahwa terdapat pengaruh yang signifikan penggunaan model pembelajaran inquiry training terhadap hasil belajar siswa diperkuat dengan nilai rata-rata kelas eksperimen lebih tinggi dibandingkan dengan nilai ratarata kelas kontrol. Hal yang sama juga dapat diketahui dari jurnal online pendidikan fisika milik Hakim, dkk 
(2012 : 11) menyatakan bahwa model pembelajaran inquiry training dimulai dengan menyajikan peristiwa yang mengandung teka-teki kepada siswa. Siswa yang menghadapi hal tersebut akan termotivasi menemukan jawaban masalah yang diberikan guru sehingga siswa lebih aktif dibandingkan menggunakan model pembelajaran konvensional.

Model inquiry training menuntut siswa untuk lebih aktif dalam pembelajaran dan mengajak siswa untuk menyelidiki secara langsung mengenai masalah yang telah disampaikan pada awal pembelajaran. Model pembelajaran ini menghadapkan siswa pada situasi yang membingungkan sehingga siswa tergugah untuk mencari tahu sendiri jawaban dari permasalahan yang ada.

Model pembelajaran inquiry training terdiri dari 5 tahapan yaitu : menghadapkan siswa pada masalah, mengumpulkan data verifikasi yaitu dengan mendorong siswa untuk mengajukan pertanyaan atas permasalahan yang telah dipaparkan dan dijawab dengan "ya" atau "tidak", kemudian mengumpulkan data melalui eksperimen, selanjutnya mengolah data hasil eksperimen, dan tahap yang terakhir adalah menganalisis proses inkuiri.

Tahap pertama, peneliti menghadapkan siswa pada masalah dengan seperti memperlihatkan visualisasi berupa video kepada siswa atau langsung memberikan pertanyaan berupa masalah yang akan diselidiki, kemudian siswa diminta untuk memperhatikan dengan seksama. Namun pada pertemuan I hanya sedikit siswa yang memberikan jawaban namun belum disertai alasan yang tepat. Pada pertemuan ke II dan III, ada peningkatan siswa yang memberikan jawaban dan memberikan alasannya dengan tepat.

Tahap kedua, peneliti mendorong siswa untuk bertanya seputar masalah yang sudah dipaparkan. Tetapi pada awalnya siswa masih kurang mengerti untuk mengajukan pertanyaan yang harus dapat dijawab dengan "ya" ataupun "tidak". Pada pertemuan selanjutnya, siswa semakin terlatih untuk membuat pertanyaan seperti yang diharapkan. Kemudian peneliti membentuk siswa kedalam 5-6 orang dalam satu kelompok dan siswa diminta untuk duduk bersama temanteman sekelompoknya.

Selanjutnya peneliti membagikan LKS, dan meminta siswa untuk memaparkan hipotesis mereka mengenai masalah yang sudah ada didalam LKS tersebut sebelum dilakukan eksperimen untuk membuktikan hipotesis mereka. Setelah itu peneliti membagikan alat dan bahan kepada masing-masing kelompok dan setiap kelompok diminta melakukan percobaan sesuai dengan LKS yang telah dibagikan. Pada pertemuan I, siswa masih kurang terbiasa dalam melakukan eksperimen atau menganalisis sehingga siswa membutuhkan banyak bimbingan dalam melakukan praktikum. Tetapi pada pertemuan selanjutnya siswa mulai terbiasa melakukan eksperimen atau menganalisis dan kegiatan percobaan menjadi lebih terarah serta siswa semakin memahami tugas yang harus mereka kerjakan seperti yang tertera pada LKS. Setelah memperoleh data hasil eksperimen, peneliti membimbing siswa untuk mengolah dan menganalisis data hasil percobaan dan menarik kesimpulan dari eksperimen yang telah mereka lakukan. Pada tahap terakhir, siswa mempresentasikan hasil diskusi yang telah mereka lakukan didepan kelas.

Nilai rata-rata postes pada kelas eksperimen tergolong dalam kategori tidak tuntas sebab belum melewati batas KKM yaitu 75. Hal ini dikarenakan KKM sekolah yang tergolong tinggi sehingga tidak sesuai dengan kemampuan awal siswa. Selain itu dalam penelitian, instrumen yang digunakan seperti LKS lebih 
menekankan siswa ke arah teori saja namun pada instrumen kognitif lebih banyak menekankan siswa dalam perhitungan, sehingga masih ada siswa yang sulit untuk menjawab dari instrumen kognitif tersebut. Tetapi model pembelajaran inquiry training ini memiliki pengaruh terhadap hasil belajar siswa hal ini dapat dilihat dari hasil belajar siswa kelas eksperimen yang mana hasil pretes 33,33 dan hasil postesnya menjadi 71,97 sedangkan untuk kelas kontrol yang diajarkan dengan pembelajaran konvensional memiliki hasil pretes 32,00 dan hasil postesnya menjadi 63,81. Sehingga diperoleh peningkatan hasil belajar di kelas eksperimen sebesar 38,64 \% sedangkan di kelas kontrol sebesar $31,81 \%$ maka dapat diketahui bahwa peningkatan hasil belajar di kelas eksperimen lebih tinggi dibandingkan di kelas kontrol. Namun jika melihat dari nilai masing-masing siswa diperoleh 14 siswa dari seluruh jumlah siswa 39 orang atau $35,89 \%$ siswa yang mencapai KKM dan 25 orang siswa atau 64,10 \% siswa yang belum mencapai KKM. Pada kelas kontrol diperoleh nilai rata-rata postes sebesar 63,81 dengan kriteria penilaian tidak tuntas ataupun belum melewati batas KKM. Dilihat dari masing-masing siswa diperoleh 4 orang siswa dari seluruh jumlah siswa 35 orang atau $11,42 \%$ siswa yang mencapai KKM dan 31 orang siswa atau $88,57 \%$ siswa yang belum mencapai KKM. Dari hasil perhitungan tersebut diperoleh bahwa lebih banyak siswa yang memperoleh nilai diatas KKM adalah siswa pada kelas eksperimen dibandingkan kelas kontrol.

Penelitian ini sejalan dengan penelitian yang dilakukan oleh Tumanggor (2012) menyatakan bahwa nilai rata-rata hasil belajar di kelas yang menggunakan model pembelajaran inquiry training adalah 74,63 sedangkan dengan menggunakan model pembelajaran konvensional memiliki nilai rata-rata 68,13 . Hasil penelitian ini terlihat bahwa ada perbedaan rata-rata hasil belajar yang cukup signifikan.

Hasil pengamatan yang dilakukan oleh observer di kelas eksperimen pada pertemuan pertama rata-rata aktivitas siswa sebesar 59,40 dengan kategori cukup aktif. Namun dipertemuan kedua rata-rata aktivitas sebesar 63,42 dengan kategori aktif. Pertemuan ketiga rata-rata aktivitas sebesar 67,95 dengan kategori aktif sampai dengan pertemuan keempat rata-rata aktivitas sebesar 73,33 dengan kategori aktif. Berdasarkan hasil pengamatan diperoleh rata-rata aktivitas siswa secara keseluruhan sebesar 66,02 termasuk ke dalam kategori aktif. Ternyata, aktivitas siswa yang dikategorikan sejalan dengan peningkatan hasil belajar siswa. Dalam hal ini, aktivitas siswa memiliki pengaruh yang positif terhadap hasil belajar.

Model pembelajaran inquiry training dapat meningkatkan hasil belajar dan aktivitas siswa yang lebih baik dibanding pembelajaran konvensional, namun selama peneliti melaksanakannya masih ada kesulitankesulitan yang dihadapi diantaranya yaitu Peneliti juga mengalami kesulitan dalam pengalokasian waktu yang masih sedikit dimana pada saat kelompok mempresentasikan hasil diskusi tidak semua kelompok dapat mempresentasikan hasil diskusinya serta peneliti masih sulit untuk membimbing siswa membuat pertanyaan yang menghasilkan jawaban 'ya' atau tidak. Model ini akan lebih baik jika peneliti mampu membagi waktu untuk setiap fasenya secara efisien terkhusus pada fase mengolah dan merumuskan penjelasan karena pada tahap ini hampir semua siswa ingin menampilkan semua hasil diskusinya untuk memberikan masukan-masukan pada siswa dikelompok lain serta sebaiknya peneliti lebih membimbing siswa agar mampu membuat pertanyaan yang 
menghasilkan jawaban "ya" atau "tidak".

\section{KESIMPULAN DAN SARAN Kesimpulan}

Berdasarkan hasil penelitian yang diperoleh maka dapat disimpulkan bahwa hasil belajar fisika siswa pada materi pokok suhu dan kalor dengan menerapkan model pembelajaran inquiry trainingmemiliki nilai rata-rata pretes 33,33 dan nilai rata-rata postes adalah 71,97 dengan kategori tidak tuntas, hasil belajar fisika siswa dengan mengunakan pembelajaran konvensional memiliki nilai rata-rata pretes 32,00 dan nilai rata-rata postes 63,81 dengan kategori tidak tuntas, aktivitas belajar siswa yang diajar dengan menerapkan model pembelajaran inquiry training memiliki persentase nilai rata-rata sebesar 66,02 dengan kategori aktif maka dapat diketahui bahwa ada pengaruh yang signifikan penggunaan model pembelajaran inquiry training terhadap hasil belajar siswa pada materi pokok suhu dan kalor di kelas X semester II SMA PAB 8 Saentis Deli Serdang T.P. 2014/2015.

Saran

Saran yang dapat peneliti ajukan berdasarkan pembahasan yaitu Untuk peneliti selanjutnya diharapkan lebih mengoptimalkan pengoorganisasian dalam kelompok dikarenakan observer yang ada untuk mengawasi siswa dalam proses pembelajaran cukup terbatas, untuk peneliti selanjutnya agar lebih membantu siswa dalam memotivasi dan memberikan arahan kepada siswa mengenai jenis pertanyaan yang digunakan dalam pembelajaran inquiry training ini, selama proses pembelajaran berlangsung sebaiknya lebih memperhatikan efisiensi waktu disetiap tahap model pembelajaran inquiry training.
DAFTAR PUSTAKA

Hakim, A., Nasution, H., dan Derlina, (2012), Perbedaan Hasil Belajar Siswa Yang Dibelajarkan Dengan Model Pembelajaran Inquiry Training Dan Konvensional Pada Materi Pokok Gaya Dan Hukum Newton Di Kelas VIII SMP Negeri 17 Medan, Jurnal Online Pendidikan Fisika1: 8-16.

Hayati, dan Suyati, R. D., (2013), Efek Model Pembelajaran Inquiry Training Berbasis Multimedia Dan Motivasi Terhadap Hasil Belajar Pada Pokok Bahasan Kalor Siswa SMP Negeri 9 Palu, Jurnal Online Pendidikan Fisika2: 24-33.

Joyce, B., Weil, M. dan Calhoun, E., (2011), Models of Teaching: Model-Model Pembelajaran Edisi Kedelapan, Pustaka Pelajar, Yogyakarta.

Mudyahardjo, R., (2008), Pengantar Pendidikan, Rajawali Pers, Jakarta.

Sirait, R., (2012), Pengaruh Model Pembelajaran Inquiry Training Terhadap Hasil Belajar Siswa Pada Materi Pokok Usaha dan Energi Kelas VIII MTS N-3 Medan, Jurnal Pendidikan Fisika1: 21-26.

Sirait, R., dan Sahyar, (2013), Analisis Penguasaan Konsep Awal Fisika Dan Hasil Belajar Fisika Pada Pembelajaran Menggunakan Model Inquiry Training Pada Materi Listrik Dinamis,Jurnal Online Pendidikan Fisika2: 1-8.

Sucita, E., (2013), Pengaruh Model Pembelajaran Inquiry Training Terhadap Hasil Belajar Siswa Pada Materi Pokok Listrik Dinamis Kelas $X$ Semester II SMAN 1 Percut Sei Tuan T.P. 2012/2013., Skripsi, FMIPA, Unimed, Medan.

Trisno, Kendek, Y., dan Pasaribu, M., (2014), Pengaruh Model Pembelajaran Training Inquiry Terhadap Hasil Belajar Pada 
Pokok Bahasan Kalor Siswa SMP Negeri 9 Palu, Jurnal Pendidikan Fisika Tadulako2: 14-20.

Tumanggor, M., (2012), Pengaruh Model Pembelajaran Inquiry Training Terhadap Hasil Belajar
Siswa Pada Materi Pokok Suhu dan Kalor Di kelas X Semester II SMA Negeri 1 Pancur Batu T.P 2011/2012., Skripsi, FMIPA, Unimed, Medan. 